\title{
Expectation, Affection and Responsibility The Charismatic Journey of a New Buddhist Group in Taiwan
}

\author{
Ji Zhe \\ Nova Religio: The Journal of Alternative and Emergent Religions, 12(2):48-68, 2008.
}

\begin{abstract}
This article explores how charismatic building and grouping are made possible, and how charisma, as a specific type of social relational structure, determines collective religious actions. Through a case study of a lay Buddhist charismatic leader, Li Yuansong, and his reformist group, Modern Chan Society, in contemporary Taiwan, the author argues that charisma stems from social interactions focusing on the extraordinary and taking place between a leader and followers, during which three decisive socio-psychological dispositions-expectation, affection and responsibility-call for and reinforce each other. Forming and moving around these three axes, charisma paradoxically links reality and utopia, submission and autonomy, domination and sacrifice. It implies a continual circle, in which hope, care and trust circulate as gifts and counter-gifts.
\end{abstract}

Sometimes the ambiguity of a concept is an asset rather than a disadvantage for stimulating research: such is the case of Max Weber's definition of charisma. As Clifford Geertz has pointed out, this concept has suffered from an uncertainty of referent from the very beginning, notably regarding the sources of charisma. ${ }^{1}$ On the one hand, Weber considered charisma a selfdetermined and inherent property of individuals, a "gift" of God, accessible only to an extraordinary leader who "is set apart from ordinary people and treated as endowed with supernatural, superhuman, or at least specifically exceptional powers or qualities." 2 On the other hand, he insisted that charisma is rooted in the recognition of the followers rather than in the charismatic leader him/herself. The latter has to know how to display his/her extraordinary quality in practice. Without the external validation of the ordinary followers, the leader's gift means nothing. ${ }^{3}$ Yet, precisely due to this ambiguity or "two-fold character," ${ }^{4}$ Weber's concept of charisma has evolved into two main lines of analysis, one focusing on the leader's personal attributes, the other on the social context in which charismatic authority emerges, a context that is often characterized as crisis.

Both lines of analysis have proved fruitful, but each runs the risk of falling into a pitfall: the former individual reductionism and the latter structuralist reductionism, ${ }^{5}$ and a score of scholars have tried to find a third way in between. Among them, Geertz has achieved some prominence by seeking to articulate "what it is that causes some men to see transcendence in others, and what it is they see." ${ }^{\prime}$ Following Edward Shils, ${ }^{7}$ Geertz found that what connects the individual's charisma and the social validation could be a sort of symbolic construction referring to the "centers" of social order. What is interesting for us here is not Geertz's specific exploration of 
charisma in line with his symbolic anthropology, but his approach that reconnects the sociology of culture with social psychology. Compared with the unilateral psychological or sociological study of charisma, such an approach does seem more faithful to Weber's style. As suggested by Geertz himself, the very force of Weber's theory lies precisely in its complexity and its ability to hold different ideas together in a single basket. To respect the complexity of Weber's theory, then, a good study on charisma should strive to develop the multiple thematic strands in Weber's concept and uncover the dynamics of their interplay, rather than collapse it into just one of its dimensions.

In the same spirit, the present article is an effort to re-examine the two-fold character of charisma. Indeed, for this purpose, we do not need to contravene Weber at all. To find a way out of the apparent ambiguity of Weber's concept of charisma, it is enough to re-read Weber in the light of Emile Durkheim's sociology. As Pierre Bourdieu reminds us, "Durkheim was...not so naïve as is claimed when he said...that 'society is God'." 8 Accordingly, if God is a metamorphosis of society and if charisma is a gift of God or of the divine, charisma is necessarily a "gift of society." That is to say, charisma does not come from some mystic or mysterious, and therefore unfindable, place, but is simply rooted in the effect of consecration of the interactions between a leader and his or her followers, between agency and structure, between individual and society. In such interactions, the ability of the (potential) charismatic leader to embody the collective consciousness may result in the continuous justification and even mystification of the leader's superiority. This prompts the core question of the present article: what kind of social exchanges articulate the charismatic leader's individual consciousness/action and the followers' collective consciousness/action, so that the personal quality of a leader can be recognized as extraordinary or sacred? To answer this question, I identify three analytical categories - based on sociological debates on charisma and my own fieldwork experience on Buddhism in Chinese societies - which fit into both the psychological and the sociological explanations of charisma: expectation, affection and responsibility.

The expectation of followers is a crucial factor in the grouping around a charismatic leader. In her study on the neorural apocalyptic communities in France, Danièle [Hervieu-]Léger pointed out that all the charismatic leaders she met showed a personal aura "which enabled them to favorably meet the group's expectations of any person liable to embody in some way collective utopia." According to her, the charismatic leaders could be recognized primarily as those capable of giving to each member of the community "an emotional response to an extraordinary appeal which fulfils an individual expectation." ${ }^{10}$ Recently, Stephan Feuchtwang and Wang Mingming proposed a definition of charisma more explicitly centered on the question of expectations, based on their fieldwork on four local religio-political leaders in contemporary China. For them, charisma consists precisely of "an expectation of the extraordinary:",

It is the expectation of finding an agency through which a turn of fortune towards utopia will be brought about in historical time...The proof, the bearing and the conduct of an admired charismatic leader all confirm followers' confidence in an expected power of transformation, modest or grand. ${ }^{12}$

Not all expectations can engender charisma. As [Hervieu-]Léger, Feuchtwang and Wang have clearly noted, only expectations which aim for something utopian, or more generally, for the extraordinary, are charismatic. From the socio-psychological perspective, the extraordinary does not suggest a mysterious source of power, but the realm where the collective affection is 
mostly easily mobilized, and affection is precisely the center of the charismatic relationship. According to Weber, if charismatic domination is distinctive from the pure traditional and rational-legal power structures, it is because charisma can move followers to "complete personal devotion to the possessor of the quality, arising out of enthusiasm, or of despair and hope."13 Such complete emotional attachment and voluntary submission to a leader does not necessarily occur in traditional or institutional domination. That is why, to a great extent, the charismatic group could be seen as an "emotional community," where the affective reward is the key of the social aggregation. ${ }^{14}$ Some authors have even clamed explicitly that charisma is nothing but an affective relationship between followers and their leader, towards whom sentiments of awe and enthusiasm are directed. ${ }^{15}$

Yet, along with expectation and affection comes, or must come, the charismatic leader's recognition of his/her responsibility, at least to a certain degree. In reality, in a charismatic group, the followers' expectation will not entirely be fulfilled by an arbitrary imposition of whatever new vision of the world the leader offers, even though sometimes the leader seems capable of doing so. Most likely, to gain and retain charisma, a leader must be endowed with responsiveness to his/her followers' needs so as to keep his/her gift socially relevant and meaningful. In this sense, the charismatic innovator "does not strike the canvas of history with the force of his individuality, but deftly reaches into the historical situation to create a value order that is ripe for the time." ${ }^{16}$ For the same reason, Bourdieu argued that the prophet as a typical religious charismatic leader does not present an ex nihilo creation of religious capital. According to him, a successful prophet simply succeeds in saying what should be said in a certain social situation. ${ }^{17}$ On the other hand, as we have mentioned, the charismatic interactions must involve an emotional attachment between followers and their leader. Yet, such emotional attachment cannot be unilateral. Except in the case of pure spiritual manipulation, it is impossible for a charismatic leader not to be sentimentally engaged when he mobilizes others. This emotional investment must arouse a sense of responsibility. In fact, charismatic leaders are often emotionally aware of their duty as the representative of the collective hope, and they may even make great sacrifices for the cause of the group.

With these preliminary theoretical considerations in mind, I shall try to reconstitute a history of a Taiwanese lay Buddhist charismatic leader, Li Yuansong (1957-2003), and his reformist group, the Modern Chan Society (Xiandaichan). Such reconstitution is based primarily on documents published by the group itself and on my fieldwork in 2004 among Li's disciples in Taipei. In this case study, I analyze how expectation, affection and responsibility function as decisive parameters in the charismatic building and grouping, and how charisma, as a specific type of social relational structure, determines collective religious actions.

\section{INCARNATION OF EXPECTATION: LI YUANSONG AND HIS MODERN CHAN (BEFORE 1994)}

In the contemporary Taiwanese Buddhist landscape, the Modern Chan Society (MCS), founded at the end of the 1980s, was a rather small group in comparison with giant organizations such as the Tzu Chi Foundation, Buddha Light Mountain, and Dharma Drum Mountain. The reform movement initiated by MCS, because of its radical character, does not represent mainstream Taiwanese Buddhism. However, from a sociological viewpoint, MCS is a 
remarkable case for exploring the reconfiguration of power relations in the modern Buddhist field. ${ }^{18}$ In fact, unlike other lay Buddhist groups that have voluntarily subjected themselves to monastic authority, MCS challenged the monks' religious privileges and advocated equality between monks and lay believers. It claimed independent authority for itself in the transmission of the Dharma, and even established its own "lay clergy." Thus, relations between MCS and the monasteries - the traditional Buddhist institutional apparatus - became competitive rather than hierarchical or complementary.

Such a radical reform could not come into being without a revolutionary charismatic leader: Li Yuansong. ${ }^{19}$ According to his autobiography, ${ }^{20} \mathrm{Li}$ was born in a poor miner's family in 1957 , in the village of Shiding, Taipei country. His family's poverty forced him to drop out after primary school, and help his parents in selling fruit. When he was thirteen, influenced by his mother, Li converted to Yiguandao - a popular religion that, by its own definition, unifies all Chinese major religious traditions - and he remained a follower for nine years. Li was a gifted boy. Only seven days after his conversion to Yiguandao, he became a little "preacher." To prepare for his teaching duties, he read the classics and thus made his first formal acquaintance with Daoist, Buddhist and Confucian traditions. Subsequently, through contacts with university students, he began reading scholarly works, such as essays on philosophy and psychology. In the early 1980s, he converted to Buddhism and began to immerse himself in the writings of Yinshun (1906-2005), a very influential monk in contemporary Chinese Buddhism. At the same time, Li also read many other Buddhist classics. Now convinced that the Buddhist understanding of the universe and life was much deeper than that of Yiguandao, $\mathrm{Li}$ abandoned the latter and became a devout Buddhist.

Some years later, Li felt the need to go beyond the mere study of Buddhist doctrine. He had become convinced that an abyss separated his current reality from the state of deliverance described in the scriptures. Frustrated that his intellectual understanding had no power to resolve this problem, and finding no teacher capable of guiding him towards deliverance, Li assiduously devoted himself to the practice of Chan meditation, day and night. From 1985 onwards, and in spite of working full-time, he practiced seated meditation for eight or more hours a day for about three years, undergoing what he described as small, intermediate and large enlightenment experiences which altogether numbered nearly one hundred.

The decisive moment came in March 1988. The month before, Li had asked himself a series of fundamental questions, such as: is the doctrine of "conditioned co-arising and non-self" (yuanqi wuwo) really true? And who can prove it? For eleven days he meditated on these questions. Suddenly, while he was meditating, a drumbeat sounded in his ears. With that "bang," Li broke through all of "the erroneous views of time, space and all existence which lie buried in the heart of all humanity" and his heart was at peace.

Soon after this decisive enlightenment, Li began to show others his way to Buddhist salvation. Step by step, in the course of teaching, he elaborated his doctrine, convened a group around him and translated his self-proclaimed religious quality into genuine charisma. In March 1988, Li started to teach Chan in a Buddhist cultural center and at the home of one of his friends in Taipei. The next year, he published his first book, based on his classroom teaching, Talking about Modern Chan with Modern People, ${ }^{21}$ which was highly successful. In April 1989, Li founded the Modern Chan Society with his friends and assistants. Within a year, Li had attracted more than 1,500 followers, 200 of whom were formally MCS members. A publishing house, an editorial office, ten practice centers, several organizations and a foundation were successively set up within the framework of MCS. In 1994, the membership had reached 12,000. ${ }^{22}$ 
From the very start, Li set out to make a radical critique of contemporary Taiwanese Buddhism. In his view, times had changed, and Chan had to adapt itself to modern life and to provide an alternative theory and practice corresponding to modern people's mentalities. Unfortunately, he continued, contemporary Buddhism, being uncharitable, sectarian and devoid of true religious practice, could only cling to outdated rules and thus fail to satisfy the needs of modern people. ${ }^{23}$ In such a context, the essential ideas of Buddhism were not properly understood by its followers. Hardly anyone was following the path to deliverance from suffering, and no one was able to clearly expound a systematic method for Buddhist salvation. Thus, Li called for reform and proposed his Modern Chan based on his own enlightenment, conceived for modern people and compatible with the spirit of the times characterized by "rationality, humanity and openness." 24 In March 1992, MCS published its "Ten Principles," 25 which can help us understand what Li meant when he defined his Chan as "modern." The main ideas of this declaration are the following:

1. Sensual passion and desire must be directed rather than repressed.

2. The scientific and humanitarian spirit must become the basis of the Buddhist religious life. We must rethink the doctrines of traditional Buddhism, which are opposed to the modern spirit.

3. Those wishing to follow the "Way of the Bodhisattva" (pusadao) must first take to heart the lives of those around them. They should not give up their responsibilities and lay duties to practice Buddhism.

4. For Buddhists, the most important thing is the Dharma, and not monastic discipline. The Dharma is the eternal truth, while the monastic rules were drawn up more than two thousand years ago and have become unacceptable for most people today.

5. Enlightenment is difficult to achieve, but not impossible. All of us have the potential to achieve salvation during our lifetimes.

6. As the religion of wisdom, Buddhism must place the emphasis on wisdom rather than on supernatural powers and charitable works.

7. Buddhism must be deeply concerned with teaching. It is wrong for it to spend most of its resources on building great monasteries.

8. All Buddhists are capable of embodying the "three treasures" of Buddhism ${ }^{26}$ provided that he or she lives wisely and compassionately, according to the Dharma.

9. A good Buddhist should believe that the Dharma is the ultimate truth, but he may also recognize other religions as pathways to truth.

10. MCS is an organization with its own genealogy, its own disciplinary rules and its own institutions. At the same time, MCS aims to form a pure, warm, affective, grateful and disciplined religious group.

At the end of 1992, Li summed up the difference between Modern Chan and traditional Buddhism in nine points, later calling them the "Hallmarks of the Modern Chan Society,"27 which were in substance identical to the earlier "Ten Principles." As one of Li's disciples pointed out, ${ }^{28}$ four of the above Modern Chan principles were especially provocative in the eyes of conservative Buddhists and gave rise to heated debates: respect for sensual passion and desire, disavowal of traditional Buddhist monastic discipline, the claim that enlightenment and deliverance are not so difficult to attain during one's lifetime, and the demand for an equal status of lay Buddhists and monks. Indeed, it was precisely these reformist ideas that attracted Li's followers, because they promised a new order highly meaningful to many lay Buddhists: enlightenment within secular life. 
In the orthodox Buddhist tradition as classically understood, the disparity of religious status is quite clear. For some orthodox Buddhists, perfect deliverance is accessible only to monks who devote themselves entirely to a disciplined otherworldly life, while the secular life of lay people is often described as the source of suffering and ignorance. That is why, in general, monks are considered to be religiously superior to lay Buddhists. In contrast to this conservative view, Li claimed that "the Buddha hall could be situated in a secular place." ${ }^{29}$ For him, everyday life in the secular world was not an obstacle to Buddhist salvation, but the very place where enlightenment and deliverance could be attained. Instead of what he called "outdated" and "inapplicable" monastic discipline rooted in the original Buddhist reaction to ancient Indian society, Li proposed a Chan practice

(1) In the midst of all the activities engaged in by people of all walks of life; (2) In the midst of fulfilling our secular responsibilities and duties; (3) with pleasure, and in accordance with our interest and mood; (4) In the midst of sorting out our thoughts and getting to understand ourselves; (5) In the midst of rational debate and the pursuit of truth to its farthest reaches. ${ }^{30}$

For him, the preconditions for being a modern Buddhist consist first in the simple expression of "whatever passions and desires" one has, "as long as they do not go against the law or harm others," so that one can experience a free and open mind; and second, in "cultivating rationality and a humane personality." "31 This humanization of Buddhism, which is surely influenced by Taixu (1890-1947) and his disciple Yinshun's "This-worldly Buddhism" (renjian fojiao) but focused more specifically on lay Buddhists' salvation, was much appreciated by some young and educated lay Buddhists ${ }^{32}$ who had been disappointed by the stereotyped style and conservative vision they found in traditional Buddhism. For many of Li's followers, Modern Chan practice did not mean an intensive, closed, other-worldly-oriented engagement that conflicted immediately with family and professional life, but rather a rational, light-hearted and promising experience that allowed them to realize themselves in everyday life. ${ }^{33}$ One of them showed his gratitude to Li thus:

The Dharma taught by Master Li allows us to achieve liberation in the midst of all the activities engaged in by people of all walks of life and surrounded by passions and desires. What a compassionate, extraordinary and wonderful (shusheng) Dharma! ${ }^{34}$

Furthermore, Li's affirmation that one can reach enlightenment rapidly and directly even in secular life fit well with the expectation of many Buddhists, which was a key factor in Modern Chan's success. Certainly, this idea is not completely new. Sudden enlightenment in everyday life was first expounded by the southern Chan school in medieval times. At the same time, in twentieth-century monastic (i.e., "orthodox") Buddhism, few Buddhists have been recognized as enlightened during their lifetimes. More commonly, it has been acknowledged only after an eminent monk's death that he had accomplished saintliness. In this respect, Li's claim that one does not necessarily need to practice for an infinitely long time to reach enlightenment was seen as audacious. Li elaborated a sophisticated system of disciplines for attaining Chan enlightenment in thirteen steps, which was summarized by him as a "combination of Concentration and Insight" (zhiguan shuangyun) for deeply entering the "Inherent Scene" (bendi fengguang). ${ }^{35}$ He promised that such a method would lead followers to "express the Bodhisattva 
spirit to the maximum possible extent within an observable period of time, and attain thorough liberation.. ${ }^{36}$ Such a promise naturally stimulated enthusiasm among lay Buddhists. One of Li's early disciples admitted frankly that if he and some others were attracted by $\mathrm{Li}$, "the most important reason is that $\mathrm{Li}$ was the only provider of enlightenment." ${ }^{37}$

Li presented himself as a model of his teaching, calling himself an " $a r h a t^{38}$ liberated by wisdom." That is to say, he was not a "great arhat" endowed with some miraculous power, but someone who was spiritually awakened. On other occasions, he also identified himself as "the one who was attributed twelve spiritual virtues of an enlightened, who knows the Way and has released himself determinedly from the three perplexities" or as "a Buddhist practitioner learning the Way of the Bodhisattva with the pure eyes of the Dharma." 39 Such self-proclaimed virtue could not but raise doubts and criticisms, but Li remained steadfast. According to him, it was hypocritical and irresponsible that a Buddhist could not recognize his own enlightenment. ${ }^{40}$ Moreover, when answering questions from his followers, Li once stated that since many people considered themselves unqualified to attain enlightenment today in an age of "Dharma decline" $(m o f a),{ }^{41}$ it was all the more necessary to insist on the feasibility of self-enlightenment in order to cure their self-abasement. Indeed, quite a few Buddhists redirected their thirst for salvation thanks to Li. They freed themselves from the pessimistic Buddhist ideology about the degenerate era of Dharma decline and regained their self-confidence about religious achievement. ${ }^{42}$ In Li's courage for reform, capacity for teaching, and self-confidence for enlightenment, they saw their own religious destiny. For them, Li was not just one master among others, but a "pharos," a "light," a "living Sutra of Wisdom,"

\section{BOND OF AFFECTION: COMMUNITY-BUILDING DURING THE “RETREAT" (1994-2003)}

Between 1988 and 1994, the social influence of MCS grew continuously. In addition to offering numerous lectures and training courses, MCS organized a wide range of activities in Taiwan, such as the "Promotion of Dharma in all Taiwan" and the "Movement of Awakening of All the People." Within MCS, Li established a "Sangha of Bodhisattvas" of 500 to 700 persons as the core of his group, and trained instructors who even created their own "streams." In spite of this growth, however, and quite unexpectedly, MCS declared in June 1994 that the movement would begin a "Retreat" (qianxiu) for two years. During that period its activities would not be open to the public, and the publication of its monthly magazine and recruitment of disciples were provisionally halted. In 1996, MCS decided to extend its Retreat for a further two years, and again in 1998. The Retreat actually continues to this day, even though MCS was re-affiliated to the Pure Land (jingtu) school of Buddhism in 2003.

$\mathrm{Li}$ explained his decision to recall his mission (the Retreat) as follows. His original aspiration for MCS had been to train real Chan masters, to found a pure and fraternal lay clergy, to promote a correct vision of Buddhism, and to spread the Modern Chan method. Yet, with the expansion of MCS, administrative concerns had become ever more complex and it had become difficult to recruit competent assistants in sufficient numbers. Moreover, very few people really wished to follow the Buddha's Way. Most adherents sought only to lead successful lives, to find a peaceful existence, and to stay healthy. According to $\mathrm{Li}$, in such circumstances, if the group had continued its rapid growth, it would have run the risk of losing its clarity, its capacity for introspection, and 
its will to reform. Therefore, to remain true to its ideals, MCS had to embark upon a Retreat in order to purify itself. ${ }^{44}$

From a sociological perspective, MCS's reversal reveals a paradox of the institutionalization process, which most new religious groups have to confront in the course of their development. In fact, when there is only a small number of members in a new religious group, it is not difficult for them to share the same collective consciousness. The group can function adequately under the direct management of its leader. Yet, as the number of members grows and their activities diversify, the group must draw on more complex organizational techniques. This leads to institutionalization based on the division of labor and on the adoption of proper procedures. Because of the impersonal character of institutional administration, relationships within the group tend to become anonymous and abstract. The emotional intensity of the collective activities might weaken, and the members may feel they grow gradually more distant, so that their participation becomes nominal rather than substantial. ${ }^{45}$ Thus, the more successfully the group develops, the more deeply it is institutionalized, and the more it risks losing its original emotional vigor.

To a certain degree, the MCS Retreat from 1994 on can be seen as a reaction to this institutionalization dilemma, which consists in returning to a communal ethos centered on a direct, personalized interaction. This choice was crucial if $\mathrm{Li}$ and MCS wished to maintain their charismatic character. In fact, charisma is not only determined by the content of the leader's response to his followers' expectation, but also by the manner in which the leader conveys the message. If a leader is capable of communicating in an emotional way with followers so that the latter's submission to him/her is voluntary and full of pleasure, s/he will have a greater chance of gaining and retaining charisma. Such emotional communication is not necessarily excluded in an institutional structure; nevertheless, it is more easily sustained in a small community.

By the same logic, we can understand why in July 1996, when Li decided to extend the MCS Retreat, he suggested that his followers move into the same housing compound, so that members who were ready to devote themselves to Modern Chan could live closely together. Very quickly, a number of Li's disciples moved with their families to the "New Village of Fengqiao" (Fengqiao xincun), in the southwest of Taipei City, where Li and three other MCS core members were living. Li named the new MCS settlement "Xiangshan Practitioners' Community" (Xiangshan xiuxingren shequ) after the name of the nearby Elephant Hill (Xiangshan). By 2001, the Xiangshan Practitioners' Community had taken its stable shape with more than one hundred households owning or renting apartments in the same area. ${ }^{46}$

Not all members of the MCS were authorized to establish themselves in the Xiangshan Community. To be admitted, a formal application had to be submitted for collective examination by the Community. Rejections were not rare. For example, an artist had to wait for more than one year to be authorized to move in, and a Buddhist scholar has been turned down twice. According to the MCS rules, if somebody moved in without the permission of the Community, his or her relation with MCS would be automatically discontinued, and he or she would no longer have a right to participate in any of the collective activities.

Thus the Xiangshan Practitioners' Community was only composed of the elect. Once a MCS member was admitted to reside in the Community, his or her family would benefit from both the support of the collectivity and Li's personal guidance in everyday life. The community was divided into sub-groups of about ten persons each. Members of a sub-group were to help each other and meet together at least once a week. There was also a committee managing affairs at the community level, but the institutional framework remained quite informal. Li was entirely at his 
followers' disposal and never delayed providing personal support. He himself helped the newcomers to design their apartments and to find new jobs. Any member who fell ill would receive his care and encouragement. Those facing family problems could see him immediately for advice. Moreover, Li committed himself to looking after the next generation of community members. The idea was to make children "happy, intelligent and endowed with character." Under Li's direction, a "reading party of Little Bees" was regularly held, where he taught the children Chinese traditional ethics in person. Li's total commitment deeply moved his followers. Full of gratitude, the community members considered that it was "the greatest happiness" in their life for them to follow $\mathrm{Li}$, their "benefactor" and "big canopy" of protection. ${ }^{47}$

Indeed, the MCS Xiangshan Practitioners' Community was more than a group for mutual aid based on spatial proximity. It was, above all, a community devoted to a "religious cause" (daoye). The sub-group was a basic unit for collective religious learning and discussion. Each month, a general gathering presided by Li was held, open to all MCS members, including those who did not live in the Xiangshan Community. Nonetheless, mutual aid and religious ideals were inseparably linked within MCS. Together, they contributed to the cementing of a bond of affection between Li and his followers. Actually, it is mutual aid that guaranteed communal confidence and cohesion. Such confidence and cohesion are rather rare in modern urban society, and constitute by themselves a testimony to the relevance of Modern Chan. "At home" in the community, members had a strong feeling of being loved and chosen, which necessarily reinforced their belief and trust in Master Li. On the other hand, the religious ideal of the Community, which consisted of training modern Chan masters in the framework of a pure lay Buddhist clergy, and was symbolized and guaranteed by Li's presence, gave the Community a utopian and sacred character. As a member pointed out, "Our community gives thoughtful attention to every member. Yet, such attention is given completely from the position of Truth (dao)." ${ }^{48}$ With this spiritual concern, the Xiangshan Community distinguished itself from other secular social gatherings. The members' mutual aid became meaningful; their emotional devotion to Li was justified. One of Li's disciples wrote about the extent to which such a bond of affection contributed to linking the community-building and the leadership-building in a charismatic group:

The Xiangshan Practitioners' Community is a Pure Land, where there is no discord, no dispute, no scheming against one another. There are only affection and fraternity (youqing youyz); there are only "happiness, intelligence and character." For this, the reason is nothing else than the presence of a master, as an incarnation of the Sutra of Wisdom. ${ }^{49}$

\section{THE IMPERATIVE OF RESPONSIBILITY: RE-AFFILIATION FROM CHAN TO PURE LAND (2003 AND AFTERWARD)}

During its Retreat from 1994 to 2003, MCS remained a noted reformist group within the Buddhist field in Taiwan and China, even though it declined to admit new members. In 1995, four volumes of Li's teachings were published in mainland China, and received both warm appreciation and sharp criticism from mainland readers. They were soon reprinted, to a total run of $80,000 .{ }^{50}$ In 1999 , MCS launched its Internet website, where the main ideas of Modern Chan 
were elaborated. During the following years, this website became very famous among Buddhists, and the number of its visitors soon surpassed one million.

Yet, a dramatic turn of events took place in 2003. From 18 May to 8 July of that year, while the SARS epidemic was spreading over East Asia, Li Yuansong gave a series of nine lectures at the Xiangshan Practitioners' Community about life and death, in which, confounding all expectations, he encouraged his followers to abandon Modern Chan and to re-affiliate themselves with the Pure Land school. In contrast to Chan, which seeks experiential wisdom and self-conscious awakening, Pure Land is a faith-oriented branch of Chinese Buddhism focused on salvation through the Amitabha Buddha (Amituofo). Its principal doctrine is that Amitabha Buddha will grant rebirth in his "Pure Land" to anyone who believes in him and recites his name. Even though some Buddhists tried and continue to try to combine Chan practice and Pure Land doctrine, there remain nevertheless some distinct incompatibilities between them. At the most basic level, Chan emphasizes enlightenment by self-effort, while Pure Land aims at salvation through grace.

What Li proposed to his followers was not a combination, but a veritable re-affiliation resulting from careful reflection. In May 2003 when his lectures on Pure Land began, Li wrote in a letter to two friends:

Recently, there are some changes in my life, both subjectively and objectively...I have promised to my followers in MCS that I would...spend all my life in the Xiangshan Community and assume my unavoidable responsibility as fully as possible. I made this promise long ago. Now is the time when I must fulfill my promise. ${ }^{51}$

If the subjective change referred to his reorientation toward the Pure Land school, the objective change was Li's health. Li had been ill for several years but in 2003, his condition seriously worsened. Feeling himself close to death, Li wrote an open letter to all Buddhists on 16 October, in which he presented himself no longer as a self-enlightened master and a Buddhist reformer, but as an "ordinary man" (fanfu):

As an ordinary man, I fall ill. Facing this disease, I have been feeling since the end of September the uselessness of all my past practice, which plunges me into severe doubts. Finally, what I once called my "enlightenment of the Way" (wudao) now seems to be nothing more than my own arrogance. I feel profound regret that some of my insights on Modern Chan are impure and inadequate. For that, I sincerely implore the forgiveness of Buddha, Bodhisattvas, Dharma Guards, all sages, good men and good women. Now, I wholeheartedly vow to be reborn into the Pure Land. I can only rely on the Amitabha Buddha. Namo Amitabha. 52

In fact, in September, Li had established contact with a monk of Pure Land school, Master Huijing (b. 1950). Li had previously known some of Huijing's publications, but had never met him. After several phone conversations with this monk, however, Li confirmed his decision to convert himself to the Pure Land school. The conversion was soon effected and Huijing granted Li a new Buddhist name, Jingsong. Then all of Li's followers in the Xiangshan Community were in turn converted to Pure Land school. In November 2003, as ordered by Li, the MCS "Assembly of the Instructors for the Transmission of Dharma" was dissolved, and the "House Rules of the Modern Chan Society" were abolished. The group was renamed as "Amitabha Society for Collective Practice" (Mituo gongxiuhui), and the Xiangshan Practitioners' Community became 
"Amitabha Village." Master Huijing was invited to serve as the teacher of the new Society, while Li forbade members to continue to call him "Supreme Master" (shangshi), and asked them to stop the publication of his writings. The MCS website was also shut down. For all intents and purposes, MCS had come to its end.

One month later, on 10 December 2003, Li Yuansong passed away. In accordance with his last will, he was tonsured and buried as a monk by Master Huijing. The day of his death was the seventeenth day of the eleventh month in the Chinese lunar calendar - the birthday of Amitabha Buddha.

Since then, bearing in mind Li's exhortations, former members of the MCS have devoted themselves to the recitation of Amitabha Buddha's name. The old conference hall has been redecorated as a collective recitation hall, with the image and statue of Amitabha occupying the central place. Two daily sessions of collective recitation were held in the morning and in the afternoon, a discipline maintained even during holidays. Beginning in January 2005, the number of daily recitations was increased to three, with an additional session in the evening. A new website was opened in January 2006, focused entirely on Pure Land doctrine, without any trace of the Modern Chan. ${ }^{53}$

How can we make sense of the MCS demise? Does it mark Li's failure as a charismatic leader? I argue that it absolutely does not. Indeed, MCS's collective re-affiliation from Chan to Pure Land is further proof of Li's charisma. Completely devoted to Li, his followers, apparently free of doubt, engaged on the new path to salvation indicated by Li, even though this new path was an apparent reversal. Yet, why did Li insist on converting all his followers to Pure Land school before his death? A possible interpretation can be found in the specificity of the charismatic relation structure.

Charisma may provoke a very strong attachment of followers to the person of their leader. This characteristic of charisma facilitates the mobilization of followers and the maintenance of group unity, but it also jeopardizes group continuity, since the persistence of a charismatic group depends greatly on the life of leader. If the leader disappears, the group's cohesion runs the risk of dissolving. Even if the leader can formally transmit his/her charge to someone else, the charisma itself is not really transmissible.

This problem affected MCS and Li Yuansong was aware of it. Li knew that he was a charismatic leader. It was not because of a sudden impulse that he asked his followers to call him "the one who recites Buddha's name," then "the one who believes in the Buddha," instead of "Supreme Master"; rather, it was in order to, as he said himself, "consciously eliminate the charismatic $\left[\right.$ kelisima $\left.^{54}\right]$ authority of 'Li Yuansong'." 55 Moreover, he had attempted several times to transmit the leadership to some eminent, elected or appointed disciples, but without ever realizing such a transmission of power. Even though his desire to transmit his leadership was certainly sincere, he could not change the simple fact that his presence in the group continued to make him the real leader. Here again, it is true that charisma depends on those who recognize it rather than the person who carries it.

On the other hand, Li clearly understood that, being considered an enlightened master physically present in this world, he was the guarantor of the possibility of salvation for his devout followers. He was endowed with a power over them, but at the same time he also had the duty to insure their deliverance, or at least uphold their hope of deliverance. That is what $\mathrm{Li}$ meant when he spoke of his "unavoidable responsibility." Consequently, if the transmission of leadership had to happen, it was necessary that the new leadership could continue to fulfill the 
followers' expectation of salvation, otherwise MCS would risk total disorientation and even dissolution. Considering all of this, Li finally found a solution in the belief in Amitabha Buddha.

Compared with Chan, the Pure Land method is relatively simple: salvation completely depends on the grace of Amitabha Buddha. Neither an experience of enlightenment nor a deep understanding of Buddhist doctrine is required. The sole discipline is the sincere recitation of Amitabha Buddha's name. With no exception, all who believe in Amitabha Buddha and recite his name will be guided by this savior to the Pure Land at the last moment of their life. Accordingly, believers in Amitabha Buddha do not need a living person to support their belief, and the crisis caused by the disappearance of the charismatic leader might be avoided.

Thus, feeling the approach of death, $\mathrm{Li}$ transferred his leadership to the eternal savior Amitabha Buddha so as to ensure his followers' salvation, at the cost of his own Modern Chan invention:

To repeat the name of Amitabha Buddha with faith is a recitation without care of the distinction between true and false. If you really understand this principle, when the last minute of your life comes, even if I am not with you, even if no master is at your side, you already have the surest support: "Namo Amitabha." So, wherever you are, you will have the light. ${ }^{56}$

What has happened after Li's death should make him satisfied. In spite of his absence, former MCS members do keep both their trust in Buddhist salvation and their communal solidarity. A charismatic group continues to exist even without a living charismatic leader: isn't this a remarkable result of Li's sense of responsibility? Such responsibility is implied by charisma itself, which may even move a leader to reject all that he has achieved in the higher interest of his followers.

\section{CONCLUSION}

Lin Zhenzhen, the spouse of an MCS active member, wrote a text honoring Li Yuansong's memory, taking the perspective of a close observer but non-adherent. ${ }^{57}$ In this text, she asked whether the success of the MCS Xiangshan Practitioners' Community as a realized utopia where people live in contentment can be attributed to the veneration of a hero, Li Yuansong. For her, what makes such a utopia possible is a set of three organizational parameters rather than Li's personal appeal: a value system for self-realization, a network of social support based on affection and fraternity, and a distribution of resources according to individual needs and virtue. This analysis coming from a quasi-insider is certainly inspiring, and it overlaps to a great extent with my own field observation. Nevertheless, as we have seen, the powerful effect of a leader's personal magnetism is not separate from the group's collective force: they are interlocked and woven together in what we call "charisma."

My argument has been that charisma stems from social interactions focusing on the extraordinary and occurring between a leader and followers, during which interactions, expectation, affection and responsibility evoke and confirm each other. The followers' expectation of the extraordinary gives rise to an emotional attachment to their leader; such collective affection bestows a sacred power on the leader, and at the same time, confers on him an unavoidable responsibility to close the gap between this ordinary world and his followers' expectation. In turn, the commitment of the leader to assume his responsibility towards the group reinforces his followers' confidence in the future, their emotional engagement in the collectivity 
and their willing submission to the leader. In terms of Marcel Mauss' theory of social exchange, charisma implies a continual circle of gifts involving leader and followers, in which hope, care, and trust circulate as gifts and counter-gifts. ${ }^{58}$ On the other hand, if leader and followers constitute charisma together, they are also constituted by charisma, just as any donor and recipient are constituted by the reciprocal and irrevocable bond of gift. Sometimes a leader's decision and the group's choice come as surprises, such as the MCS Retreat and re-affiliation. Yet, in the final analysis, all these individual and collective religious actions, reactions and interactions have their own logic tied to the charismatic relation structure, which are sociologically and psychologically intelligible.

In summary, charisma is a mechanism that articulates individual calling and collective voluntary following, and it is also an outcome of this mechanism. Constituting and negotiating three axes - expectation, affection and responsibility - charisma paradoxically links reality and utopia, submission and autonomy, domination and sacrifice. Full of tensions, it can include at the same time all four types of social actions distinguished by Weber-instrumentally rational action, value-rational action, emotional action, and traditional action ${ }^{59}$ — and links both the "ethics of conviction" and the "ethics of responsibility." Such extraordinary richness explains why one century after its first appearance in the social sciences, charisma remains a promising subject of research.

My thanks to Vincent Goossaert, David Ownby as well as the anonymous reviewers from Nova Religio who read the earlier version of this paper for their comments and corrections.

\section{ENDNOTES}

\footnotetext{
${ }^{1}$ Clifford Geertz, "Centers, Kings, and Charisma: Reflections on the Symbolics of Powers," in Clifford Geertz, Local Knowledge: Further Essays in Interpretive Anthropology (NewYork: Basic Books, 1983): 121-46.

${ }^{2}$ Max Weber, Economy and Society, ed. Guenther Roth and Claus Wittich (New York: Bedminster Press, 1968), 241.

${ }^{3}$ Weber, Economy and Society, 241-2; 1114-5.

${ }^{4}$ William H. Friedland, "For a Sociological Concept of Charisma," Social Forces 43, no. 1 (1964): 18-26.

${ }^{5}$ See Martin E. Spencer, "What Is Charisma?" The British Journal of Sociology 24, no. 3 (1973): 341-54; Takis S. Pappas, "Political Charisma and Liberal Democracy," paper presented at the international conference "Penser la démocratie. Autour de l'œuvre de Juan Linz," Montpellier, France, 7-9 September 2006, <http://www.afsp.mshparis.fr/activite/2006/colllinz06/txtlinz/pappas2.pdf>, accessed 15 July 2008.

${ }^{6}$ Geertz, "Centers, Kings, and Charisma," 122.

7 Edward Shils, "Charisma, Order, and Status," American Sociological Review 30 (1965): 199-213.

8 Pierre Bourdieu, Pascalian Meditations, trans. Richard Nice (Stanford, Calif.: Stanford University Press, 2000 ), 245.

9 Danièle [Hervieu-]Léger, "Charisma, Utopia and Communal Life. The Case of Neorural Apocalyptic Communes in France," Social Compass 29, no. 1 (1982): 41-58, see 44.

${ }^{10}$ Léger, "Charisma, Utopia and Communal Life," 48.

${ }^{11}$ Stephan Feuchtwang and WANG Mingming, Grassroots Charisma: Four Local Leaders in China (London and New York: Routledge, 2001), 6, 172.

12 Feuchtwang and Wang, Grassroots Charisma, 172.

13 Weber, Economy and Society, 242.
} 
${ }^{14}$ See Danièle Hervieu-Léger and Françoise Champion, Vers un nouveau christianisme? (Toward a New Christianity?) (Paris: Cerf, 1986); Françoise Champion and Danièle Hervieu-Léger, ed., De l'émotion en religion. Renouveaux et traditions (On Emotion in Religion: Renewals and Traditions) (Paris: Centurion, 1990). For critics of the term "emotional community" (Gemeinde/Bund) in sociology, see Jeanne Favret-Saada, "Weber, les émotions et la religion" ("Weber, Emotions, and Religion"), Terrain 22 (1994): 93-108; Kevin Hetherington, “The Contemporary Significance of Schmalenbach's Concept of the Bund," The Sociological Review 42, no. 1 (1994): 1-25.

15 For example, see Spencer, "What Is Charisma?"

${ }^{16}$ Spencer, "What Is Charisma?" 347.

17 Pierre Bourdieu, "Genèse et structure du champ religieux" ("The Genesis and Structure of the Religious Field"), Revue française de sociologie 12, no. 3 (1971): 295-334, see 333.

18 Ji Zhe, "The Establishment of a Lay Clergy by the Modern Chan Society: Some Logics in the Field of Modern Chinese Buddhism," China Perspectives 59 (2005): 56-65.

${ }^{19}$ This section on Li Yuansong and the early history of MCS is based on my article "The Establishment of a Lay Clergy by the Modern Chan Society." I am grateful to MCS for providing me with unpublished English translations of Li Yuansong's works by Brook A. Ziporyn, which helped me improve my own translations.

${ }^{20}$ LI Yuansong, Xiri ceng wei meihua zui bugui-Jingyanzhuyi de xiandaichan (Once I was Drunk with the Plum-tree Flower and Forgot to Go Home. Modern Chan of Empiricism) (Taibei: Xiandaichan chubanshe, 1996), 178-212.

${ }^{21} \mathrm{Li}$ Yuansong, Yu xiandairen lun xiandaichan (Talking about Modern Chan with Modern People) (Taibei: Wenshu chubanshe, 1989).

22 For a brief history of the first stages of the development of MCS, see ZHENG Zhiming, "Li Yuansong yu xiandaichan" ("Li Yuansong and Modern Chan"), in Zheng Zhiming, Taiwan dangdai xinxing fojiao — chanjiao pian (Contemporary New Buddhism in Taiwan. Volume Chan) (Jiayi: Nanhua guanli xueyuan, 1998): 331-99.

${ }^{23}$ See Li Yuansong, Xiandairen ruhe xuechan — chaoyue xinling de maodun yu bu'an (How Modern People Learn Chan: Beyond the Contradictions and Anxieties in Heart) (Taibei: Xiandaichan chubanshe, 1994), 68-76; Li Yuansong, Chan de chuanxi (Transmission and Learning of Chan) (Taibei: Xiandaichan chubanshe, 2000), 213-84.

${ }^{24}$ Li Yuansong, Chan de xiuxing yu chan de shenghuo (Chan Practice and Chan Life) (Taibei: Xiandaichan chubanshe, 1994), 278-82.

25 "Fojiao xiandaichan shixiang jianchi" ("Ten Fundamental Principles in Modern Chan Buddhism") Xiandanchan yuekan (Modern Chan Monthly) 27 (March 1992), 1.

26 The Buddha, the Dharma and the Sangha. Traditionally, only the monastic authority is the legitimate representative of the "three treasures" in this world.

${ }^{27}$ See Li, Xiandairen ruhe xuechan, 86-92.

${ }^{28}$ ZHANG Jiayin, "Xiandaichan jiqi sixiang tese" ("Modern Chan and the Features of Its Thoughts"), Shijie hongming zhexue jikan 12 (2000), < http://harmonia.arts.cuhk.edu.hk/ cculture/library/hongming/200012-003.htm>, accessed 15 July 2008.

${ }^{29} \mathrm{Li}$, Xiri ceng wei meihua zui bugui, 92.

${ }^{30}$ Li Yuansong, Gu xianren dao (Way of Ancient Immortals) (Taibei: Xiandaichan chubanshe, 2000), 26.

${ }^{31} \mathrm{Li}$, Chan de xiuxing yu chan de shenghuo, 7-65.

32 In July 1989, three months after the foundation of MCS, Li Yuansong said in an interview that 90 percent of his 1,500 followers had an undergraduate or graduate degree, see Li, Xiri ceng wei meihua zui bugui, 99. In 1990, the average age of Li's nine eminent disciples and assistants was 36.

${ }^{33}$ See the personal accounts of Modern Chan practitioners published in the monthly Xiandanchan yuekan (from December 1989 to August 1994), the bimonthly Bendi fengguang, from March 1994 to May 1998, and BAI Yingfang, Xiaoyu, DonG Yunxia, et al., Xiandai miaohaoren-Taiwan diyige duhui xiuxing shequ (Modern Wonderful People: The First Urban Practitioners' Community in Taiwan) (Taibei: Xiandaichan chubanshe, 2000).

${ }^{34}$ Bai, Xiaoyu, Dong et al., Xiandai miaohaoren, 166.

35 See Li Yuansong, Wo you mingzhu yike—zenyang ziji dadao jietuo (I Have a Bright Pearl: How to be Liberated by Self) (Taibei: Xiandaichan chubanshe, 1993) and his Chan de xiuxing yu chan de shenghuo.

${ }^{36} \mathrm{Li}$, Chan de xiuxing yu chan de shenghuo, 16.

37 YANG Huinan, "Cong Yinshun de renjian fojiao tantao xinyushe yu xiandaichan de zongjiao fazhan" ("Religious Evolution of the Xinyu Society and the Modern Chan Society: Analysis from the Perspective of the This-worldly Buddhism of Yinshun"), Foxue yanjiu zhongxin xuebao 7 (2000): 275-312, see 310.

38 The term arhat (Sanskrit; in Chinese: aluohan) in Buddhism means "saint" who has realized certain religious goals such as the elimination of the impurities of the subject.

${ }^{39} \mathrm{Li}$, Chan de chuanxi, 244.

${ }^{40} \mathrm{Li}$, Xiri ceng wei meihua zui bugui, 149-55. 
${ }^{41}$ Mofa is the third and also the last period of the cyclic development of Buddhism in our universe. According to some Chinese Buddhist sutra commentaries and apocrypha, it began to form one thousand five hundred years after the nirvana of Sakyamuni Buddha, and would last ten thousand years, until the advent of Maitreya, the "Buddha of the future." In these "latter days of the Law" where we are living now, people have little gift for properly understanding Buddha's teaching. If some of them believe and practice Buddhism, they have unfortunately less opportunity to reach liberation than the Buddhists in the preceding eras.

${ }^{42}$ For example, see the story of Li's disciple HuANG Jinyuan, "Suifang jianmai fengliu: wo shuo wo xiu xiandaichan" ("Show My Elegance Freely: My Experience of Modern Chan"), Xiandanchan yuekan 10 (1990): 2.

${ }^{43}$ See Bai, Xiaoyu, Dong et al., Xiandai miaohaoren.

${ }^{44} \mathrm{Li}$, Xiri ceng wei meihua zui bugui, 224-37.

45 Peter Berger, Brigitte Berger and Hansfried Kellner, The Homeless Mind: Modernization and Consciousness (New York: Random House, Vintage Books Edition, 1974): 185-8.

${ }^{46}$ For descriptions of the Xiangshan Practitioner's Community by its members, see Dong Yunxia, Dushi conglin: xiandaichan xiangshan xiuxing shequ (Urban Forest: the Xiangshan Practitioners' Community of the Modern Chan Society (Taibei: Xiandaichan chubanshe, 2002); HuA Minhui, "Xiandaichan jiaotuan xiangshan xiuxing shequ de fazhan" ("Development of the Xiangshan Practitioners' Community of the Modern Chan Society”), Shijie zongjiao xuekan 3 (2004): 201-8.

47 See Bai, Xiaoyu, Dong et al., Xiandai miaohaoren.

${ }^{48}$ Dong, Dushi conglin: xiandaichan xiangshan xiuxing shequ, 7.

${ }^{49}$ Bai, Xiaoyu, Dong et al., Xiandai miaohaoren, 12.

50 XING Dongfeng, "Xiandaichan jiqi yu chuantong fojiao de fenqi" ("Divergences between Modern Chan Society and Traditional Buddhism”), Jinbungaku ronsô 4 (2002): 117-31.

${ }^{51}$ Cited from Hua Minhui, "Wei chang duo jie yuan, haoshang fu qiancheng” ("In Order to Redeem a Vow Made Long Ago, Go Ahead Spiritedly"), in Li Yuansong laoshi jinian wenji (In Memory of Master Li Yuansong), ed. Jingtuzong xiangshan mituo gongxiuhui (Xiangshan Amitabha Society for Collective Practice of the Pure Land School) (Taibei: Jingtuzong wenjiao jijinhui, 2004), 201-26, see 215.

52 Wen Jinke, Jiwang yu kaixin. Cong xiandaichan dao jingtu xinyang (Based on the Past, Open to the Newness. From Modern Chan to Belief in the Pure Land) (Taibei: Jingzong chubanshe, 2005): 196-7. Namo is a Buddhist expression to show reverence or worship, often placed in front of a divine object, such as a Buddha or a sutra. In the Pure Land school, believers can recite "namo Amitabha" or simply "Amitabha."

${ }^{53}<$ http://www.purelandsect.org $>$.

${ }^{54}$ Chinese phonetic transcription of "charisma" or "charismatic."

${ }^{55}$ Li Yuansong, Xiandaichan de jiaoyu (Education of Modern Chan), (Taibei: Caituan faren xiandaichan wenjiao jijinhui, 2003), 437. In practice, Li's followers have kept calling him "Supreme Master."

${ }^{56}$ Lesson given by Li Yuansong on Pure Land in 2003, quoted by Wen Jinke, "Xiandai jingtuzong de jianli yu kaixian: du Li Yuansong laoshi 2003 nian jingtu jiujiang" "(Foundation and Revelation of Modern Pure Land Sect: Notes on the Nine Lectures Given by Master Li Yuansong about Pure Land”), <http://homepage20.seed.net.tw/web@3/unjinkr/p_17.htm>, accessed 15 July 2008.

${ }^{57}$ LIN Zhenzhen, "Cong xiangshan shequ chufa" ("Begin with the Example of the Xiangshan Commnuity"), in Li Yuansong laoshi jinian wenji, 371-6.

${ }^{58}$ The connection between charismatic interaction and the economy of salvation gifts is an issue worth further study, which could help us to go beyond the understanding of religious action based on the religious market model and rational choice theory. See Enzo Pace, "Salvation Goods, the Gift Economy and Charismatic Concern," Social Compass 53, no. 1 (2006): 49-64.

${ }^{59}$ In this paper I do not discuss the traditional dimension of charisma-building, as it lies somewhat outside of our focus on the charismatic relation structure within a group. But in fact, charisma and tradition are not as contradictory as they look. For example, each culture has its own tradition for manufacturing charisma. Even the most radical charismatic revolution needs some traditional rhetoric to legitimate the changes that it provokes. See Feuchtwang and Wang, Grassroots Charisma; see also Vincent Goossaert and David Palmer's contributions in this issue. 